т. В. Сушко, аспірантка кафедри екологічної та інженерної геології і гідрогеології (Львівський національний університет імені Івана Франка), tetiana.sushko@Inu.edu.ua, https://orcid.org/0000-0002-0215-9483
T. SUSHKO, PhD student at the Department of Ecological and Engineering Geology and Hydrogeology (Ivan Franko National University of Lviv), tetiana.sushko@Inu.edu.ua, https://orcid.org/0000-0002-0215-9483

\title{
ОСОБЛИВОСТІ ФАЦІЙ РИФІВ СИЛУРІЙСЬКОГО ВІКУ ВОЛИНО-ПОДІЛЛЯ
}

\section{FEATURES OF FACIES OF REEFS OF THE SILURIAN AGE OF VOLYN-PODILLIA}

На території Волино-Поділля силурійські відклади представлені потужними товщами теригенних і карбонатних відкладів, як-от мергелі, аргіліти, вапняки, доломіти тощо. Оскільки ці відклади мають високі колекторські властивості, вони перспективні на вуглеводні. Також глини слугують покришками для пасток нафти й газу. У промисловості їх часто використовують як будівельний матеріал.

Промислових скупчень вуглеводнів у карбонатних товщах Волино-Поділля поки ще не виявлено. Утім є численні ознаки нафтогазоносності цих відкладів у силурійських і верхньодевонських вапняках. У карбонатних товщах силурійського віку наявні нафтогазоперспективні рифогенні вапняки у трьох горизонтах: скальському, малиновецькому й баговицькому. Вони утворюють бар'єрний риф, який простягається від району Локачинського валу на північному заході до м. Чернівців на південному сході.

Дослідження має на меті визначити поширення рифових фацій силуру Волино-Поділля та горизонтів у цих відкладах; уточнити їхню стратиграфічну належність; показати роль тектонічних рухів у формуванні фацій і товщини рифогенних відкладів, а також окреслити можливості пошуків вуглеводнів у силурійських рифогенних утвореннях.

Ключові слова: Волино-Поділля, силурійські відклади, рифогенні горизонти, вуглеводні.

On the territory of Volyn-Podillya Silurian deposits are represented by thick strata of terrigenous and carbonate deposits, they are mainly represented by marls, argillites, limestones, dolomites, etc. Because these deposits have excellent reservoir properties, they are promising for hydrocarbons, and clays serve as oil and gas trap covers. In industry, they are often used as a building material.

Industrial accumulations of hydrocarbons in the carbonate strata of Volyn-Podillya have not yet been identified. However, there are numerous signs of oil and gas potential of these deposits in the Silurian and Upper Devonian limestones. In the carbonate strata of the Silurian age there are oil and gas-prospecting reef limestones in three horizons: Skal, Malynovets and Bahovytsia. They form a barrier reef that stretches from the area of Lokachynsky Val in the northwest to the city of Chernivtsi in the southeast.

Some samples of the core raised from rifogenic rocks of Silurian had an oil smell, smears and inclusion of liquid oil in cracks and cavities. Sometimes whole intervals of cavernous dolomites were impregnated with light oil. During the re-drilling of rifogenic rocks, stratification of drilling mud and oil film was recorded. In the process of testing limestones of the rock horizon in W. 12-Lokachi received a small influx of oil, and in W. 1-Volodymyrivska, a gas inflow with a flow rate of 1.4 thousand $\mathrm{m}^{3} / \mathrm{day}$ was obtained from the rocks of the Bahovytsia horizon. From Malinovetsky (W. 10, 15, 17-Lokachi) and Bagovytsky (W. 15-Lokachi) horizons, inflows of formation water with a significant amount of dissolved gas (96\% methane) and oil films were obtained.

Therefore, these data indicate the prospects of exploration of hydrocarbon deposits in the riphogenic carbonate strata of the Silurian age of Volyn-Podillya and their thorough study.

The main task of this article is: to determine the distribution of reef facies of the Silurian Volyn-Podillya and horizons in these deposits. Clarify their stratigraphic affiliation. Show the role of tectonic movements on the formation of facies and the thickness of reef deposits, as well as the possibility of searching for hydrocarbons in Silurian reef formations.

Keywords: Volyn-Podillya, Silurian deposits, reef horizons, hydrocarbons.

\section{Вступ}

Волино-Подільська плита в геологічному плані розміщується в південно-західній частині Східноєвропейської платформи, на північному сході межує з Українським кристалічним щитом, а на південному заході - 3 Передкарпатським прогином (рис. 1).

Силурійські відклади поширені в Україні на території Волино-Поділля, у північно-західній частині Передкарпатського прогину та в Західному Причорномор'і. Вони є складовою частиною нижнього (палеозойського) структурного поверху осадового чохла західних областей України. Палеозойські відклади поступово занурюються на захід під кутом 30-35 , і їхня товщина в цьому напрямку збільшується. Вони утворюють монокліналь північно-західного простягання, нахилену на захід і південний захід, що ускладнюється місцевими плікативними порушеннями, флексурними перегинами та підняттями незамкненого контуру. На території Волино-Поділля вони займають велику площу і на всю товщину

Т. В. Сушко, 2021, с. 33-36 відслонюються в межах берегових схилів Дністра, а також у долинах його приток - Збруча, Тернави та інших.

Мета роботи: визначити можливість перспективності розрізу рифових фацій Волино-Поділля.

Об'єкт дослідження: фації рифів Волино-Поділля.

У геологічній історії південно-західної окраїни Східноєвропейської платформи та прилеглої частини Передкарпатського прогину середній палеозой посідає особливе місце. 3 ним пов'язане формування потужної різнофаціальної товщі силуру й девону, яка різко відрізняється від підстильних і перекривальних відкладів і є відображенням геологічних процесів, що відбувалися на краю платформи під час іiі переходу від каледонського до герцинського етапу розвитку. Характер та інтенсивність цих процесів визначалися розміщенням регіону, який у тектонічному плані належав до зони перикратонних опускань, а в палеогеографічному був дном шельфового моря.

Силурійські відклади поділяються на такі горизонти: китайгородський і баговицький (венлокський ярус нижнього відділу), малиновецький (лудлівський ярус) та скальський 


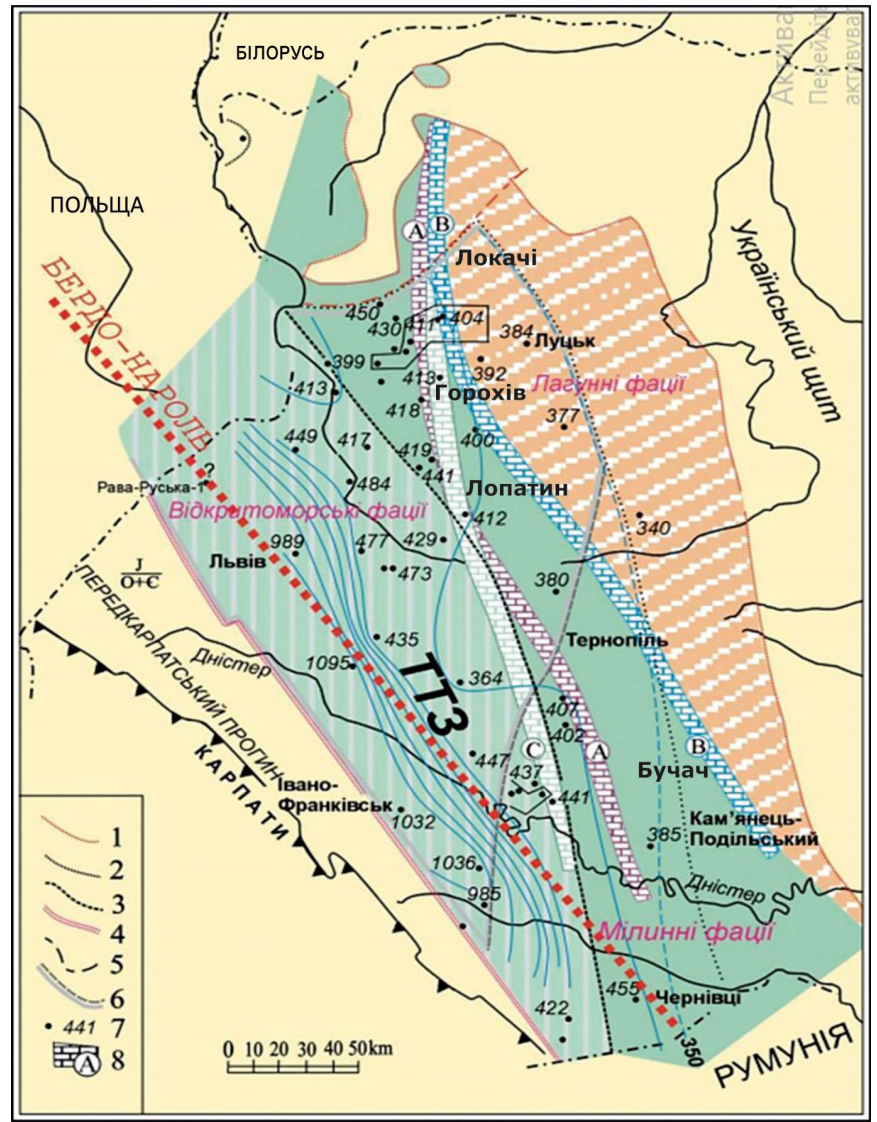

(пржидольський ярус верхнього відділу). Ці горизонти здебільшого складені вапняковими породами, товщина яких коливається в межах 350-450 м, і вапняково-глинистими - завтовшки 900 м (рис. 2).

Китайгородський горизонт (венлок) поширений у найбільш зануреній частині Львівського палеозойського прогину та в Передкарпатському прогині (у зоні Тейссейра-Торнквіста) i повністю глинистий. На території нашого дослідження його не виокремлюють.

У східній частині Волино-Подільської плити в баговицькому, малиновецькому та скальському горизонтах розвинені бар'єрні рифи, представлені різними органогенними вапняками й доломітами. У зарифових частинах розвинені доломіти 3 украпленнями та прошарками ангідритів. Смуга розвитку бар'єрних рифів простягається з південного сходу на північний захід уздовж лініі: Чернівці - Бучач - Лопатин - Горохів - Локачі (рис. 1). Силурійські відклади без стратиграфічної перерви змінюються девонськими.

На Волино-Поділлі є різноманітні найменування світ, що беруть участь у геологічній будові регіону (таблиця). У процесі силурійського осадконагромадження на Волино-Подільській окраїні Східноєвропейської платформи сформувалися різнофаціальні відклади завтовшки 340-1102 м. Мінімальні значення товщин зафіксовано в східній частині регіону та вздовж південно-східної межі Львівського палеозойського прогину, де в розрізах переважають карбонатні відклади, максимальні - у Передкарпатському прогині та центральній частині Львівського палеозойського прогину, де поширені винятково аргіліти.

Рис. 1. Карта поширення фацій силурійських відкладів [1]

1-3 - східна межа поширення відкладів (1 - силуру, 2 - тиверської серії, 3 -дністерської серіі); 4 - західна межа поширення відкладів силуру й девону; 5 - зони тектонічних порушень; 6 - межа поширення середньодевонських відкладів; 7 - товщина відкладів у свердловинах; 8 - розміщення біогермних бар'єрів (А - баговицького, В - малиновецького (конівського), С - скальського (ісаковецького) часу); ТТЗ - зона Тейссейра-Торнквіста

Рис. 2. Стратиграфічна колонка відкладів Волино-Поділля [2]

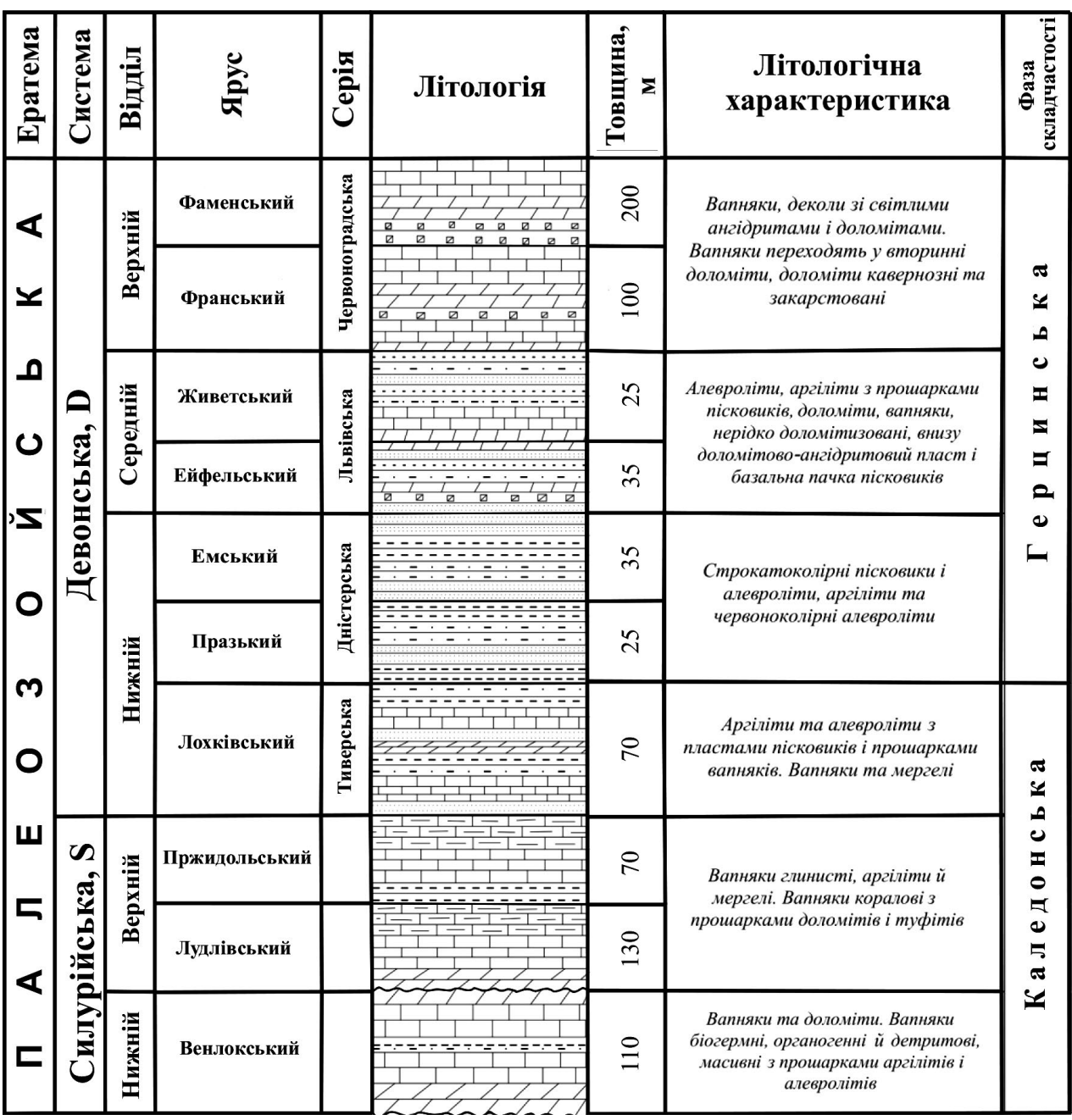


Таблиця. Характеристика світ баговицького, малиновецького і скальського горизонтів силурійських відкладів Волино-Поділля

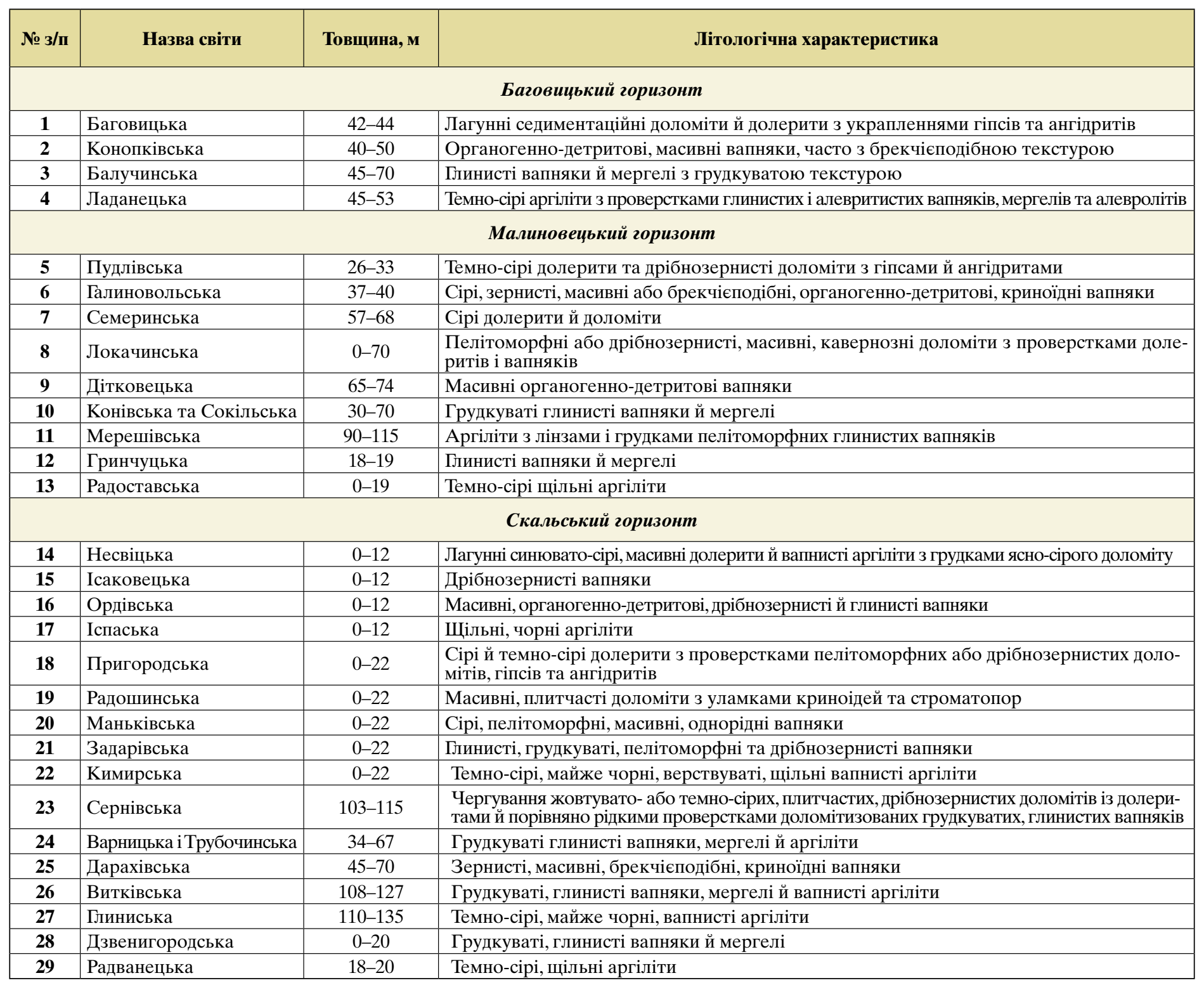

Аналіз карт поширення фацій засвідчує, що відкритошельфові фації прилягають до західного підніжжя бар'єра, який утворювали рифи, біогерми, зарослі криноідеї або вали детритових осадів на межі лагуни й відкритого палеобасейну. На їхнє розміщення, швидкість росту й горизонтальної міграції безпосередньо впливали вертикальні рухи тектонічних блоків на поздовжніх розломах, що супроводжувалися коливанням глибини в шельфовій зоні палеобасейну. Попри латеральну міграцію бар'єра й фаціальних зон, структурний план суттєво не мінявся впродовж усього силуру. Ріст органогенних побудов через їхне інтенсивне руйнування лише незначно випереджав швидкість ізохронного осадконагромадження у передрифовій і зарифовій зонах, тож вони не утворили тіл, які завтовшки перевищували б умісні товщі.

Передрифові зони складені масивними органогенно-детритовими вапняками з вклиненими в них доломітизованими продуктами руйнування рифів, що чергуються 3 лагунними відкладами.

Тектонічні рухи на краю Східноєвропейської платформи супроводилися періодичними регіональними трансгресіями й регресіями. Рухи блоків уздовж розломів не були інтенсивними й суттєво не впливали на формування фацій i розподілення товщин відкладів. Найвідчутніше в силурі проявлялися регресії в лудлівському, баговицькому та на початку скальського часу, які викликали максимальне обміління палеобасейну, інтенсивний розвиток органогенних побудов і рифів, істотне розширення на захід акваторій лагун, локальне розмиття осадів у прибережній зоні. Трансгресія в силурійському періоді досягла свого апогею в малиновецькому часі, коли майже в усьому регіоні сформувалася монотонна товща грудкуватих глинистих вапняків і мергелів відкритошельфової та перехідної зони. Такою самою за масштабом, але порівняно короткочасною була й пізньоскальська трансгресія.

Перспективи пошуків нафти й газу пов'язують із силурійськими рифогенними утвореннями. У межах Локачинського валу в біогермних спорудах є досить задовільні колекторські властивості, а саме поруватість - 10 \% і проникність $46 \cdot 10^{-3}$ мкм $^{2}$, а також безпосередні ознаки нафтогазоносності та сприятливі гідрохімічні умови.

Гідрогеологічні дослідження карбонатних комплексів венлокського, лудлівського та пржидольського ярусів за- 
свідчують, що пластові води пов'язані з тріщинно-кавернозно-поровими колекторами в органогенних вапняках і доломітах східної частини басейну та 3 вапняками глибокого шельфу на заході. Пластові води належать до хлоркальцієвого типу. Для цих водоносних горизонтів характерна висока метаморфізація, мінералізація та хлоркальцієвий тип, які вказують на умови утрудненого водообміну в силурійських відкладах [3].

Зразки керна, піднятого з рифогенних порід силуру, мали нафтовий запах, примазки і вкраплення рідкої нафти в тріщинах і кавернах. Інколи цілі інтервали кавернозних доломітів були просякнені легкою нафтою. Під час випробування рифогенних порід скальського горизонту у сверд. 12-Локачі отримали незначний приплив нафти, а у сверд. 1-Володимирівська 3 порід баговицького горизонту - приплив газу дебітом 1,4 тис. м $^{3}$ д. 3 малиновецького горизонту у свердловинах 10, 15, 17-Локачі та 3 баговицького у сверд. 15-Локачинській отримано припливи пластової води з великою кількістю розчиненого газу та плівками нафти. Ці дані свідчать про перспективність пошуків вуглеводнів у рифових утвореннях.

Згідно з результатами вивчення рифів на Локачинській площі, для них характерна мікро- і макрокавернозність 3 по-

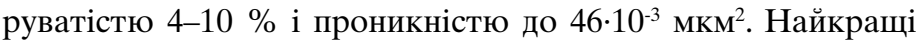
колектори спостерігаються в малиновецькому і баговецькому горизонтах. Екраном для вуглеводнів слугують глинисті вапняки з аргілітами, що перекривають їх.

Висновки. Наведені дані підтверджують перспективність розшуків покладів вуглеводнів у рифогенних карбонатних товщах силурійського віку Волино-Поділля, однак потребують дальшого вивчення. Невирішеними завданнями щодо карбонатних товщ силуру Волино-Поділля є такі:

- прогнозування порід-колекторів, порід-екранів, вірогідних пасток, регіональних і локальних зон біогермоутворення;

- уточнення порожнинного простору й колекторських властивостей бар'єрного рифу та його співвідношень із сингенетичними й епігенетичними відкладами;

- визначення геометричних параметрів біогермних споруд (довжини, ширини, товщини) та оконтурення тіла бар'єрного рифу;

- вивчення літологічного складу бар'єрного рифу та його фаціальної неоднорідності (зональності) у розрізі й по площі.

\section{ЛІТЕРАТУРА}

1. Бодлак В. П., Дриган Д. М., Колтун Ю. В., Крупський Ю. З. та ін. Нетрадиційні джерела вуглеводнів України: монографія. У 8 кн. Кн. 2. Західний нафтогазоносний регіон; Нац. акціонерна компанія "Нафтогаз України" та ін. - К.: Ніка-Центр, 2014. - 400 с.

2. Крупський Ю. З. Геодинамічні умови формування і нафтогазоносність Карпатського та Волино-Подільського регіонів України. - К.: УКрДГРІ, 2001. - 144 с

3. Крупський Ю. З. Геологія і нафтогазоносність Західного регіону України: монографія. - Львів: СПОЛОМ, 2020. - 256 с.

\section{REFERENCES}

1. Bodlak V. P., Dryhan D. M., Koltun Yu. V., Krupskyi Yu. Z. et al. Unconventional sources of hydrocarbons of Ukraine: monograph. In 8 books. Book 2. Western oil and gas region; Nat. joint-stock company "Naftogaz of Ukrain,"etc. - Kyiv: Nika-Tsentr, 2014. - 400 p. (In Ukrainian).

2. Krupskyi Yu. Z. Geodynamic conditions of formation and oil and gas potential of Carpathian and Volyn-Podilsky regions of Ukraine. Kyiv: UkrDHRI, 2001. - 144 p. (In Ukrainian).

3. Krupskyi Yu. Z. Geology and oil and gas potential of the Western region of Ukraine: monograph. - Lviv: SPOLOM, 2020. - 256 p. (In Ukrainian).

Рукопис отримано 23.08.2021.

\section{ДЛЯ ДАЛЬШОГО ПІДВИЩЕННЯ НАУКОВОГО РЕЙТИНГУ ЖУРНАЛУ ТА ЙОГО ДОПИСУВАЧІВ ВАРТО ЗВЕРНУТИ УВАГУ НА ТАКЕ:}

1. Кожна публікація не англійською мовою супроводжується анотацією англійською мовою обсягом не менш як 1800 знаків (з ключовими словами). Якщо видання не $\epsilon$ повністю українськомовним, кожна публікація не українською мовою супроводжується анотацією українською мовою обсягом не менш як 1800 знаків (з ключовими словами, ураховуючи пропуски).

2. Вимоги до анотацій англійською мовою: інформативність (без загальних слів); змістовність (відображення основного змісту статті та результатів досліджень); застосування термінології, характерної для іноземних спеціальних текстів; єдність термінології в межах анотації; без повторення відомостей, що містяться в заголовку статті.

3. Прізвища авторів статей надаються в одній із прийнятих міжнародних систем транслітерації (з української - відповідно до Постанови Кабінету Міністрів України № 55 від 27.01.2010“Про впорядкування транслітерації українського алфавіту латиницею", з російської - відповідно до "Системы транслитерации Библиотеки конгресса США"). Зазначення прізвища в різних системах транслітерації призводить до створення в базі даних різних профілів (ідентифікаторів) одного автора.

4. Для повного й коректного створення профілю автора дуже важливо зазначити місце його роботи. Дані про публікації автора використовуються для отримання повної інформації щодо наукової діяльності організацій і загалом країни. Застосування в статті офіційної, без скорочень, назви організації англійською мовою запобігатиме втраті статей у системі аналізу організацій та авторів. Бажано вказати в назві організації відомство, якому вона підпорядковується.

5. В аналітичній системі SCOPUS потрібні пристатейні списки використаної літератури латиницею. Можливості SCOPUS дають змогу проводити такі дослідження: за покликаннями оцінювати значення визнання робіт конкретних авторів, науковий рівень журналів, організацій і країн загалом, визначати актуальність наукових напрямів і проблем. Стаття з представленим списком літератури демонструє професійну ерудицію та якісний рівень досліджень її авторів.

6. Правильний опис джерел, на які покликаються автори, $є$ запорукою того, що цитовану публікацію буде враховано в процесі оцінювання наукової діяльності їі авторів, а отже й організації, регіону, країни. За статистикою цитування журналу визначають його науковий рівень, авторитетність тощо. Тому найважливішими складниками в бібліографічних покликаннях $\epsilon$ прізвища авторів і назви журналів. До опису статті треба вносити імена всіх авторів, не скорочуючи їхньої кількості. Для уникнення неточностей в ідентифікації авторства й визначення персональних метрик (показників) бібліометрії авторам наукових публікацій потрібно використовувати персональні коди ORCID.

7. Для українсько- та російськомовних статей з журналів, збірників, матеріалів конференцій структура бібліографічного опису така: автори (транслітерація), переклад назви статті англійською мовою, назва джерела (транслітерація), вихідні дані, у дужках - мова оригіналу, ідентифікатор DOI.

8. Список використаної літератури (References) для SCOPUS та інших закордонних баз даних наводиться повністю окремим блоком, повторюючи список літератури, що подається українською/ російською мовою, незалежно від того, містяться в ньому чи ні іноземні джерела. Якщо в списку $є$ покликання на іноземні публікації, їх повністю повторюють у списку, який створюють латиницею.

Рукопис статті до редакції автори подають зі своїми підписами. 